\title{
FOREIGN DIRECT INVESTMENT, TRADE OPENNESS AND GROWTH NEXUS IN LESOTHO
}

\author{
Leseko Makhetha* \\ National University of Lesotho
}

Received: June 2015

\author{
Joel Rantaoleng* \\ Lesotho Post Bank
}

Accepted: September 2016

\begin{abstract}
This paper examines the long-run relationship among FDI, trade openness and growth in Lesotho for the period 1980-2011. The results show a long-run relationship between output, FDI and trade openness. The VAR Granger causality shows a unidirectional causal relationship running from trade openness, FDI to output and from output, FDI to trade openness. FDI was found to be insignificant in explaining growth of output in both the long and short run. Trade openness was found to be significant with a negative impact on output growth in the long run but was found to be insignificant in the short run.
\end{abstract}

Keywords

Lesotho, FDI, Trade Openness, ARDL cointegration, VAR Granger causality/Block, Exogeneity Wald tests

*Mr L Makhetha is a lecturer in the Department of Economics, National University of Lesotho. [lesekomakhetha@gmail.com]

\#Mr J Rantaoleng is the customer relationship officer, Lesotho Post Bank. 


\section{INTRODUCTION}

Foreign Direct Investment (FDI) marks the fundamental features in the recent years that trend towards globalisation. FDI is believed to be a key ingredient for growth in income and employment, technology advancement, and socio-economic development parallel to improved income distribution or poverty reduction especially for developing countries (Yaoxing, 2010), and Lesotho is not an exception to this phenomenon. Lesotho, like many countries in Africa, is also open to foreign investment. According to the United Nations Conference on Trade and Development (2003), Lesotho's manufacturing sector is driven entirely by export-oriented FDI in its apparel industry.

The low level of FDI to Africa as a whole is symptomatic of the region's failure to integrate into the global economy and a principal reason why its growth performance operates under a narrow export base and low productivity levels. Inefficient production and distorted investment incentives, which discourage the entry of foreign firms and bias those that come towards less productive activities, have been a significant part of a history of misguided policies and ineffective reforms in Africa. If African policymakers were to commit themselves to establishing a competitive investment climate by integrating more fully into the global economy and becoming more transparent and inclusive in their reform efforts, these reforms would attract foreign firms and engender a competitive global investment climate in Africa, which would then translate into improved economic performance.

Ever since Ricardo launched the theory of comparative advantage to challenge the English Corn Laws, economists have been arguing for the advantages of free trade with now-familiar arguments: openness promotes the efficient allocation of resources through specialisation and comparative advantage; and it promotes competition in national and international markets and allows for easier diffusion of knowledge and technology across countries. In addition, the positive contribution of trade openness towards explaining growth stems from the notion that liberalisation encourages the division of labour, which substantially improves productivity and export capabilities. Thus recent studies postulate that trade openness and FDI play a vital role in explaining the growth phenomena in developing countries (see Dawson, 2006; Dutta and Ahmed, 2001; Estrada and Yap, 2006).

World Bank (1993) posits that the economies of countries with more trade openness relatively outperform their less open counterparts. Yaoxing (2010) suggests that the FDI-growth nexus and trade-growth nexus have as a rule concluded that both FDI inflows and trade openness promote economic growth. Yaoxing (2010) further argues that there are however clear indications that the growth-enhancing effects from FDI and trade openness vary across countries, thus resulting in diverse and, at times, conflicting empirical findings across countries.

Nonetheless, much of the FDI in manufacturing has been driven by Lesotho being a signatory to and beneficiary of some international trade and investment agreements, including the African Growth and Opportunity Act (AGOA), which gives Lesotho an incentive to export to the United States duty free. In addition, the Lesotho National Development Corporation (LNDC), which was established in 1967 with the objective of promoting investment in Lesotho. However, Malefane (2007) emphasises that the remaining challenge for Lesotho is now to improve the base for the existing foreign operations as well as to further raise its attractiveness to FDI.

The relationship between FDI, trade openness and economic growth remains one of the most important issues in the economic literature. In Lesotho in particular, research on this issue is very 
limited; therefore this paper will add to existing empirical studies of FDI and trade openness on growth. Malefane (2007) investigated the determinants of FDI in Lesotho, looking at how macroeconomic stability, regulatory framework, political stability and market size affect FDI. Their results indicate that some of the foreign enterprises in Lesotho are there to serve a bigger South African market and also that Lesotho has benefited from a more export-oriented investment promotion strategy, but the results do not show any relationship between FDI, trade openness and growth. The issue of the FDI, trade openness and growth nexus is very ambiguous across countries. Although FDI and trade openness are postulated to be the significant ingredients for growth, this may not be the case in most developing countries.

It is against this background that this paper therefore aims to remedy the neglect of the specific research on the long-run nexus of FDI, trade openness and growth in Lesotho. To assess this, the study employs the recent data analysis technique, the bounds testing cointegration approach (Pesaran \& Pesaran, 2001) and VAR Granger causality / Block Exogeneity Walds tests. The rest of the paper is structured as follows: in section 2 we provide a literature review, while section 3 offers the analytical framework. The methodology specification is described in section 4 , and the penultimate section 5 presents the empirical results and discussion. Section 6 concludes the paper with recommendations.

\section{LITERATURE REVIEW}

Although theory generally posits not only that FDI and trade openness have positive effects but also that they are perceived to be the fundamental factors in stimulating the growth of the host country, the empirical evidence however proves that the effects of FDI and trade openness are rather ambiguous. Melnyk et al. (2014) indicate that for developing countries, FDI is a way to transfer technology and capital from other countries. The authors emphasise that the current successful economic growth of a host country is explained by a catch-up effect in technological development with its trading partner. Nonetheless, some studies conversely show that FDI and trade openness can have a negative impact on domestic economies and the downfall of FDI and trade openness can be observed through the repatriation of profit and the market-stealing effect.

Borensztein, De Gregorio and Lee (1998) postulate that FDI is particularly a key ingredient of successful economic growth in developing countries because the very essence of economic development is the rapid and efficient transfer and cross-border adoption of best practices, such as managerial and technical deployment of technology from abroad. Furthermore, past empirical studies, both in cross-country and country-specific studies of the trade-FDI interaction on growth (Kohpaiboon, 2004; Mansouri, 2005), FDI-growth nexus and trade-growth nexus (Lipsey, 2000; Pahlavani, Wilson and Worthington, 2005) have concluded that both FDI inflows and trade openness stimulate growth.

In trying to determine the dynamic interaction between FDI, domestic investment and growth in Pakistan, Ullah, Shah and Khan (2014) employ the Johansen cointegration approach and TodaYamamoto causality approach to evaluate causal linkages. The empirical findings of this study reveal the existence of a long-run relationship between domestic investment, FDI and economic growth, which is further supported by Toda-Yamamoto causality. In addition, a bidirectional causality has been found between FDI and domestic investment, implying that both domestic investment and FDI cause each other. 
Furthermore, Adhikary (2011) used the Vector Error Correction model on a time series data spanning 1986-2008 in Bangladesh and the results revealed a strong link between explanatory variables and growth with unidirectional causal flows. There were positive effects of both FDI and capital formation on growth, whereas a negative but diminishing effect was observed for trade openness. According to Adhikary (2011), this could be attributable to the exchange rate depreciation, relatively high import values and negative trade balance position.

However, FDI and trade openness may have negative effects on the growth prospects of the recipient economy if they give rise to substantial reverse flows in the form of remittances of profits, and dividends and/or if the transactional corporations obtain substantial or other concessions from the host country. Saltz (1992) for instance examined the effects of FDI on economic growth for developing countries. The empirical results showed a negative relationship between growth and FDI during the period of study. Several authors found similar results (see Bos, Sanders \& Secchi, 1974). The explanation of the inverse relationship could be that the level of output stagnates in cases of FDI where monopolisation and pricing transfers might occur, which will cause under-utilisation of labour, which in turn will cause a lag in the level of domestic consumption demand and, eventually, stagnation.

Different researchers have employed different research methods in determining a relationship between FDI and growth. For instance, Belloumi (2014) examined the relationship between FDI and economic growth in Tunisia by employing the autoregressive distributed lag (ARDL) approach to cointegration for the period 1970 to 2008. The results indicated no existence of any form of Granger causality in all the variables. This suggests that despite a widespread belief that FDI can generate positive spillover externalities for the host country, the empirical finding from Tunisia fails to confirm this belief. Similarly, Adelowakan and Maku (2013) engaged the standard growth model regression to investigate the effects of trade openness and FDI on growth in Nigeria for the period 1970 to 2011. The timeframe captures the pre-, during and post-Structural Adjustment Program (SAP) periods, and the results revealed positive and negative effects of trade openness and FDI on growth respectively. Also in Nigeria, Soliu and Ibrahim (2014) examined the nexus between FDI, trade openness, capital formation and growth and observed a long-run relationship among these variables. However, FDI was found to be statistically insignificant, with a positive effect on growth, which according to Soliu and Ibrahim (2014) could be ascribed to corruption, bad governance and decay within the Nigerian economic system.

Halit (2002) also investigated the relationship between trade openness and growth, especially in the case of developed countries trading with developing countries. The author uses two types of trade openness measures to explore the relationship between trade openness and growth. In the first measure, the author used the ratio of exports plus imports to GDP and in the second measure of trade openness the author employs import penetration ratios and export shares in GDP to measure trade openness. The results revealed a negative relationship between trade openness and growth in developing countries, thus indicating that trade restrictions can, at times, lead to economic growth for developing countries.

Early studies on FDI, including those of Singer (1950) and Prebisch (1968), justify the negative effect of FDI by postulating that countries may receive very limited benefits of FDI if most benefits are transferred to the foreign investor's country. The other possibility that results in a negative correlation between FDI and growth could be that although FDI is believed to raise the level of investment, it lowers the rate of growth due to factor price distortions or misallocation of resources. Boset et al. (1974) examined the effects of FDI by U.S. companies on developing countries' growth for the period 1965-1969. Their results revealed an inverse relationship between 
the two variables. Their explanation for these results was that the outflow of profits back to U.S. exceeded the level of new investment for each year in the period of study. The other factors that caused the inverse relationship were the price distortions due to protectionism and natural resource depletion.

\section{ANALYTICAL FRAMEWORK AND DATA}

\subsection{Data definitions and sources}

In examining the nexus between FDI, trade openness and economic growth in Lesotho, this paper employs Lesotho annual time series data from 1981 to 2011 . The key variables used are output $(y)$, which is a proxy for GDP per capita, Foreign Direct Investment (FDI), which is the value of real gross FDI, Trade Openness (TO), which is the sum of export and import values to GDP ratio, and Labour stock ( $\mathrm{L}$ ), measured in terms of labour force and capital stock (K). Since capital stock is not available for Lesotho (K) is proxy by the real value of gross fixed capital formation (GFCF). Data for all variables was obtained from the World Bank Database. Nominal variables are expressed in 2001 constant prices using the consumer price index. Descriptive statistics are provided in TABLE 6 .

\subsection{Model specification}

In order to investigate the possible growth boosting effects of both FDI and Trade Openness in Lesotho, this paper essentially follows Yaoxing (2010). Data analysis is modelled using an Aggregate Production Function (APF) framework. This standard APF has been fundamentally used in the critical analyses of the impacts of FDI inflows and trade openness on growth (see Mansouri, 2005 and Kohpaiboon, 2004).

The APF is specified as follows:

$$
Y_{t}=A_{t} K_{t}^{\alpha} L_{t}^{\beta}
$$

where $Y_{t}$ denotes the aggregate production of the economy at time $t$. The variables $A_{t}, K_{t}$ and $L_{t}$ also denote the total factor productivity (TFP), the capital stock, and the labour stock at time $t$ respectively. Following Bhagwati (1985), it is assumed that FDI, trade openness and other factors, which are exogenously determined, all influence the behaviour of TFP (Bhagwati, 1985 and Edwards, 1998).

Thus

$$
A_{t} A_{t}=f\left(F D I_{t}^{\phi}, T O_{t}^{\delta}, C_{t}\right)
$$

Equation (2) can therefore be expressed as:

$$
A_{t}-F D I_{t}^{\phi} T O_{t}^{\delta} C_{t}
$$

Equations (1) and (3) therefore yield:

$$
Y_{t}=C_{t} K_{t}^{\alpha} L_{t}^{\beta} F D I_{t}^{\phi} T O_{t}^{\delta}
$$

We include the dummy variable $d 98$, which takes account of the 1998 political instability in Lesotho, thus capturing the structural breaks in the GDP, FDI and trade openness in Lesotho. We 
also include the dummy variable dLHDA, which represents the establishment of Lesotho Highland Development Authority (LHDA) from 1987-1998, which authorises the Lesotho Highlands Water Project (LHWP), a relatively big water investment project in Lesotho. Equation (4) thus becomes:

$$
Y_{t}=C_{t} K_{t}^{\alpha} L_{t}^{\beta} L D I_{t}^{\phi} T O_{t}^{\delta} d 98 d L H D A
$$

To estimate equation (5), we take the natural logs on both sides, which yields the following equation (6):

$$
Y_{t}=c_{t}+\alpha \ln K_{t}+\beta \ln L_{t}+\phi \ln F D I_{t}+\delta \ln T O_{t}+d 98+d L H D A+\mu_{t}
$$

where $\alpha, \beta, \phi, \delta$ and $\psi$ are constant elasticity coefficients of output with respect to the $K_{t}, L_{t}, F D I_{t}, T O_{t}$ and $c_{t}$ is a constant parameter and $\mu_{t}$ represents the white noise error term. In accordance with economic theory, all coefficients are expected to be positive:

That is, $f_{K} \geq 0, f_{L}, f_{T O} \geq 0$.

\section{METHODOLOGY}

\subsection{Cointegration Test}

To empirically analyse the short- and long-run relationships and dynamic interactions among the variables of interest, we first test for unit root of variables using the Phillips and Perron (PP) (1998) test in order to determine the stationarity of all variables. The PP test is preferred over the traditional Augmented Dickey-Fuller (ADF) test because of its use of non-parametric methods to adjust for serial correlation and endogeneity of regressors, thereby preventing the loss of observations implied by the ADF test. Hamilton (1994) also argues that the PP test also allows for the possibility of heteroskedastic error terms.

In testing for cointegration, numerous studies, including that by Engle and Granger (1987), have applied the cointegration approach, which is based on the analysis of residuals and Johansen's (1998) maximum likelihood reduced rank method, which have been used intensively to determine the relationship between variables in time series. However, criticisms of this method have questioned the results. Harris (1995) emphasised the statistical deficiencies of the models. Reimers (2002) also found that in a small or finite sample, Johansen's cointegration test is biased towards rejecting the null hypothesis of no cointegration. Huang and Yang (1996) also revealed that the Johansen procedure is very sensitive to the assumption that error terms are independent and normal. Lastly, Ahking (2002) observed that the results from the Johansen tests are sensitive to the choice of deterministic components. As a result Abeysinghe and Tan (1999) demonstrated that the Johansen estimator is the worst cointegration estimator.

Despite the weakness of Johansen's procedure, the cointegration test is not limited to Johansen's test. Pesaran et al. (2001) proposed an alternative cointegration test, which is based on the autoregressive distributed lag (ARDL) framework. ARDL has several advantages, including its applicability regardless of the stationarity properties, or, put differently, it applies irrespective of whether the regressors are purely $\mathrm{I}(0)$ or $\mathrm{I}(1)$, or mutually integrated. However, it is fundamental to ensure the absence of $/(2)$ series since their presence would crash the procedure meant only for $/(0)$ and $/(1)$ or mixed integrated variables. Finally, this technique is suitable even for small or finite sample, which is not the case with the Johansen procedure. Thus in this paper 
we adopt the ARDL approach to test the cointegration relationship between economic growth, FDI, trade openness, labour stock and capital stock:

$$
\begin{aligned}
\Delta \ln Y_{t}=c+\eta \ln Y_{t-1}+\alpha \ln K_{t-1}+\beta \ln L_{t-1}+\phi \ln F D I_{t-1}+\delta \ln \ln T O_{t-1} \\
\quad+\sum_{i=1}^{P} \eta_{2 i} \Delta \ln Y_{t-1} \\
+\sum_{i=1}^{q} \alpha \ln \Delta K_{t-1} \\
+\sum_{i=1}^{r} \beta \ln \Delta L_{t-1}+\sum_{i=1}^{s} \phi \ln \Delta F D I_{t-1}+\sum_{i=1}^{w} \delta \ln \Delta T O_{t-1}+\mu_{t}
\end{aligned}
$$

Where $\Delta$ denotes the first differences and all other variables are as defined earlier. The first step in the ARDL approach is to estimate equation (7) using Ordinary Least Square (OLS). The second step involves tracing the presence of cointegration in the long-run relationship among variables by restricting all estimated coefficients of lagged level variables equal to zero. That is, the null hypothesis of no cointegration $\left(H_{0}=\eta=\alpha=\beta=\delta=0\right)$ against the alternative $\left(H_{i}: \eta \neq \alpha \neq\right.$ $\beta \neq \delta \neq 0$ ).

Then the computed F-statistics are compared with the critical value tabulated in Pesaran et al. (2001). The lower bound values assume that the explanatory variables are integrated of order zero, or are $/(0)$, while the upper bound values assume that the explanatory variables are integrated of order one or are $/(1)$. Therefore, if the computed F-statistic falls below the lower bound value, $I(0)$, then the null hypothesis of no cointegration cannot be rejected. Conversely, if the computed F-statistic exceeds the upper bound value, I(I), it is concluded the variables of interest are cointegrated and thus approach a long-run equilibrium. But if the test statistic lies between the two bounds, then the results are inconclusive.

Having tested for cointegration, the next step is to estimate equation (7) using the ARDL approach. That is, selecting the orders of the model using the Akaike Information Criteria (AIC) and obtaining the short-run error correction models, specified as:

$$
\begin{aligned}
\Delta \ln Y_{t}=c+\sum_{i=1}^{q} \alpha & \ln \Delta K_{t-1} \\
& +\sum_{i=1}^{r} \beta \ln \Delta L_{t-1} \\
& +\sum_{i=1}^{s} \phi \ln \Delta F D I_{t-1}+\sum_{i=1}^{w} \delta \ln \Delta T O_{t-1}+E C M_{t-i}+\mu_{t}
\end{aligned}
$$

\subsection{Granger Causality}

After establishing the long-run relationship between FDI, trade openness and growth, the following step is to examine the Granger-causal relationship among the variables. $X$ is said to "Granger-cause" $Y$ if and only if the forecast of $Y$ is improved by using the past values of $X$ together with the past values of $Y$, than by not doing so (Granger, 1969). Granger causality distinguishes between unidirectional and bi-directional causality. Unidirectional exists from $X$ to $Y$ if $X$ causes 
$Y$ but $Y$ does not cause $X$. If neither of them causes the other, then the two time series are statistically independent. If each of the variables causes the other, then a mutual feedback exist between the variables. In order to test for Granger causality, we estimate a five variable VAR model as follows, where all variables are initially considered symmetrically and endogenously. This is given in the system of equations (9) below.

$$
\left[\begin{array}{c}
Y_{t} \\
K_{t} \\
L_{t} \\
F D I_{t} \\
T O_{t}
\end{array}\right]=\alpha_{0}+\alpha_{1}\left[\begin{array}{c}
Y_{t-1} \\
K_{t-1} \\
L_{t-1} \\
F D I_{t-1} \\
T O_{t-1}
\end{array}\right]+\alpha_{2}\left[\begin{array}{c}
Y_{t-2} \\
K_{t-2} \\
L_{t-2} \\
F D I_{t-2} \\
T O_{t-2}
\end{array}\right]+\cdots+\alpha_{p}\left[\begin{array}{c}
Y_{t-p} \\
K_{t-p} \\
L_{t-p} \\
F D I_{t-p} \\
T O_{t-p}
\end{array}\right]+\left[\begin{array}{c}
u_{t} \\
u_{t} \\
u_{t} \\
u_{t} \\
u_{t}
\end{array}\right]
$$

where $t$ is the time subscript, $p$ is the number of lags for the VAR, $\alpha_{0}$ is the vector of constants and $\alpha_{1}, \alpha_{2}, \ldots, \alpha_{p}$ are all parameter matrices and the other variables are as previously mentioned. The paper adopts VAR Granger / Block Exogeneity Wald Tests to examine the causal relationship among the variables. Under this system, the endogenous variable can be treated as exogenous. Then we employ the chi-square (Wald) statistics to test the joint significance of all other lagged endogenous variables in each equation of the model.

\section{RESULTS AND DISCUSSION}

\subsection{Unit root test}

TABLE 1: Unit Roots Results

\begin{tabular}{lcccc}
\hline & \multicolumn{2}{c}{ Level } & \multicolumn{2}{c}{ First Difference } \\
\hline Variable & Intercept & Intercept \& Trend & Intercept & Intercept \& Trend \\
\hline$y$ & 1.1618 & 0.1640 & $-5.8293 * * *$ & $-6.2943 * * *$ \\
FDI & -1.4426 & -2.1752 & $-5.1477 * * *$ & $-5.0569 * * *$ \\
TO & -0.7213 & -3.4855 & $-4.5411 * * *$ & $-4.5169 * * *$ \\
\hline$L$ & -0.1338 & $-3.4445 * *$ & & \\
\hline$K$ & -1.3622 & $-.5295 *$ & & \\
\hline
\end{tabular}

Source: Authors' analysis

$\star, \star \star, \star \star \star$ show that coefficients are statistically significant at the 10,5 , and $1 \%$ level of significance respectively.

All variables are lagged twice and the lag for tests is selected based on the Schwarz Information Criterion.

In carrying out the ARDL procedure, we test first the stationarity status of all variables to determine their order of integration. This is necessary because if time series is found to be nonstationary, the regression analysis will produce spurious results. The Phillips and Perron (1988) unit root tests are employed in order to avoid spurious regression. TABLE 1 shows that all the variables are stationary at first difference except for capital stock (K) and labour stock (L), which are stationary at level. Thus this justifies the use of the ARDL approach, since we have a mixed order of integration of variables $[(/(0)$ and $/(1)]$. 


\subsection{Cointegration tests results}

\section{TABLE 2: Cointegration Results}

\begin{tabular}{cccccc}
\hline Dependent variable & AlC lags & $\begin{array}{c}F- \\
\text { statistic }\end{array}$ & Lowerbound & Upperbound & Conclusion \\
\hline$F_{y}(y / F D I, T R, K, L)$ & 2 & 7.1914 & 3.7796 & 5.1942 & Cointegration \\
\hline
\end{tabular}

Source: Authors' analysis

TABLE 2 reveals the existence of a long-run (cointegration) relationship among FDI, trade openness, capital, labour and output growth in Lesotho. The calculated F-statistic $F_{y}(y / F D I, T O$, $K, L)=7.1914$ and it is higher than the upper bound critical value 5.1942 at the $5 \%$ level. The lag order of two was selected using the AIC. The estimated long-run results coefficients (TABLE 1 in appendix) show all variables under consideration are significant in explaining growth, except for FDI and the 1998 political instability in Lesotho (d98). However, contrary to most literature, LHDA and trade openness are found to reduce the growth of output during the study period in Lesotho. The results on trade openness are consistent with those obtained by Yaoxing (2010) and Halit (2002), who found that trade restrictions can stimulate the growth of output for developing countries.

Halit (2002) argues that the relationship between trade openness and output depends on whether a country is a developing or developed one, whether it is a big or small country and whether a country has a comparative advantage in those sectors that are receiving protection. The case of Lesotho could be explained like the case of Cote d'Ivoire (see Halit, 2002): that Lesotho has not managed to combine the opportunities offered by the world markets with domestic investment and an institution-building strategy to stimulate the spirit of domestic entrepreneurship. With LHDA (see TABLE 1 in appendix), one would expect a positive coefficient of LHDA; however, on the contrary, there is a negative coefficient. These results could be that, during the study period, the costs of investing in LHWP were not yet fully covered, thus exerting a negative impact in output growth.

FDI, unlike in most literature, is found not only to be insignificant in explaining growth of output in Lesotho, but it also has a negative impact on the output growth. This is consistent with the results obtained by Bos et al. (1974), Ramirez (2000), Katerina, Papanastasiou and Vamvakidis (2004) and Seetanah (2009). The general explanation for these results is that FDI may not lead to growth in developing countries because multinational corporations tend to operate in imperfectly competitive sectors with high barriers to entry or a high degree of concentration. As a result, FDI may crowd out domestic savings and investment. Furthermore, it is also associated with high income inequality and high external dependence. Moreover, FDI may have a negative impact on the external sector because profit repatriation will tend to affect the capital account negatively.

The short-run dynamic coefficients associated with the long-run relationships obtained from the ECM equation (8) are given in TABLE 2. The short-run relationships reveal that all the variables under consideration are significant in explaining the output growth in Lesotho except trade openness. However, the results indicate that about $10 \%$ increase in FDI would lead to about $1 \%$ decline of output growth in Lesotho. About $1 \%$ increase in both capital stock and labour stock would lead to an increase of about $7 \%$ and $34 \%$ respectively of output growth in Lesotho in the short run. 


\subsection{Causality test results}

TABLE 3: VAR Granger Causality / Block Exogeneity Wald Test Results

\begin{tabular}{|c|c|c|c|c|}
\hline $\begin{array}{l}\text { Dependent } \\
\text { variable }\end{array}$ & $\begin{array}{c}\text { Excluded } \\
\text { variable }\end{array}$ & Chi-square & $\begin{array}{l}\text { Degrees of } \\
\text { statistic }\end{array}$ & $\begin{array}{l}\text { P-value } \\
\text { freedom }\end{array}$ \\
\hline \multirow[t]{2}{*}{ y } & TO & 0.617052 & 2 & 0.7345 \\
\hline & FDI & 8.160559 & 2 & 0.0160 \\
\hline \multicolumn{2}{|c|}{ All values taken together } & 10.10712 & 4 & $0.0387 * \star$ \\
\hline \multirow[t]{2}{*}{ TO } & y & 10.36120 & 2 & $0.0056 * \star \star *$ \\
\hline & FDI & 0.579041 & 2 & 0.7478 \\
\hline \multicolumn{2}{|c|}{ All values taken together } & 10.92312 & 4 & $0.0274 * \star$ \\
\hline \multirow[t]{2}{*}{ FDI } & y & 1.278623 & 2 & 0.5277 \\
\hline & TO & 0.581242 & 2 & 0.7478 \\
\hline \multicolumn{2}{|c|}{ All values taken together } & 3.102153 & 4 & 0.5409 \\
\hline
\end{tabular}

Source: Authors' analysis

$\star * *(* *)$ and $*$ indicate the rejection of the null hypothesis at the $1(5)$ and $10 \%$ level of significance, respectively

TABLE 3 depicts the causality results. The objective of this test is to determine the causal relationship among the FDI, trade openness and growth, which is essential in showing the direction of causality among these variables. There are essentially three possible causal relationships to this test. There could be a unidirectional, bi-directional or neutral relationship.

A chi-square statistic of 8.16 for FDI with reference to output $(y)$ represents the hypothesis that a lagged coefficient of FDI in the regression equation of $y$ is equal to zero $(0.0160)$. Thus FDI is a Granger causal for $Y$ at 0.0169 , but TO does not Granger-cause Y. In other words, output is influenced by foreign direct investment but not by trade openness. Nonetheless, the hypothesis of block exogeneity is rejected when $y$ is taken as dependent variable $(0.0387)$. This suggests that output is influenced by foreign direct investment and trade openness when they are jointly taken.

When TO is taken as dependent variable, the results reveal that TO is influenced by $\mathrm{Y}(0.0056)$ but not by FDI (0.7486). However, $Y$ and FDI jointly influence TO (0.0274). The null hypothesis of block exogeneity is accepted when FDI is taken as a dependent variable. This means that foreign direct investment is not influenced by both output and trade openness. The results reveal a unidirectional causal relationship running from trade openness, foreign direct investment to output and from output, foreign direct investment to trade openness. But no causal relationship running from output, trade openness to FDI was found.

\section{CONCLUSION AND RECOMMENDATIONS}

The objective of this paper was to empirically examine the long-run interrelationship among FDI, trade openness and growth in Lesotho. To achieve this purpose, we employed the bound testing cointegration approach suggested by Pesaran and Pesaran (2001) and VAR Granger causality / 
Block Exogeneity Wald Tests. The results reveal the evidence of a long-run relationship between output, FDI and trade openness over the period 1980-2011. The VAR Granger causality / Block Exogeneity Wald tests show a unidirectional causal relationship running from trade openness, FDI to output and from output, FDI to trade openness, but no causal relationship running from output, trade openness to FDI. FDI was found to be insignificant in explaining growth of output in both the long and short run. These results are consistent with those that were found by Soliu and Ibrahim (2014) in Nigeria, except that their results showed that FDI had a positive effect on growth. Trade openness was found to be significant, with a negative impact on output growth in the long run, but was found to be insignificant in the short run. As a policy recommendation, it is recommended that the government of Lesotho should make an effort to give the necessary incentives to attract FDI given its relative importance to growth. There should also be a significant improvement in domestic infrastructure, as the availability of better-quality and more reliable services in all aspects of infrastructure are key ingredients of an environment conducive to business. The government of Lesotho should also engage in international governing arrangements. Most importantly, Lesotho needs to properly manage the combination of the opportunities offered by the world markets with domestic investment and an institution-building strategy to stimulate the spirit of domestic entrepreneurship.

\section{LIST OF REFERENCES}

Abeysinghe, T. and Tan, K. (1999). Small sample estimation of a cointegrating vector: an empirical evaluation of six estimation techniques. Applied Economics Letters, 6, pp. 645-648.

Adelowakan, 0.A. and Maku, A.0. (2013). Trade openness, foreign investment and economic growth in Nigeria: a long-run analysis. European Journal of Globalization and Development Research, 7(1), pp. 446-458.

Adhikary, B.K. (2011). FDI, trade openness, capital formation and economic growth in Bangladesh: a linkage analysis. International Journal of Business and Management, 6(1), pp. 16-18.

Ahking, F.W. (2002). Model misspecification and Johansen's co-integration analysis: an application to the US money demand. Journal of Macroeconomics 24, pp. 51-66.

Belloumi, M. (2014). The relationship between trade, FDI and economic growth in Tunisia: an application of the autoregressive distributed lag mode. Econ. Syst. (2014), Available at:

http://dx.doi.org/10.1016/j.ecosys.2013.09.002 (Accessed 13 May 2017)

Bhagwati, J.N. (1985). Investing abroad: Esmee Fairbain Lecture, Lancaster University. Reprinted in V.N. Balasubramanyam (ed.) JN Bhagwati, Writings on International Economics. (1997, Delhi, Oxford University Press)

Borensztein, દ., De Gregorio, J. and Lee, J.W. (1998). How does foreign direct investment affect economic growth? Journal of International Economics 45, pp. 115-135.

Bos, H.C., Sanders, M. and Secchi, C. (1974). Private foreign investment in developing countries: a quantitative study on the macroeconomic effect: a quantitative study of the evaluation of the macro-economic effects. International Studies in Economics and Econometrics 7. Netherlands: Springer.

Dawson, P.J. (2006). The export-income relationship and trade liberalization in Bangladesh. Journal of Policy Modeling, 28, pp. 889-896. 
Dutta, D. and Ahmed, N. (2001). Trade liberalization and industrial growth in Pakistan: a cointegration analysis. University of Sydney, Australia. (Working paper series NWS 2006).

Edwards, S. (1998). Openness, productivity and growth: what do we really know? Economy Journal, 108(447), pp. 383-398.

Engle, R.F. and Granger, C.W.J. (1987). Cointegration and error correction: representation, estimation and testing. Econometrica 55(2), pp. 251-276.

Estrada, M.A. and Yap, S.F. (2006). The openness growth monitoring model (OGM-Model). Journal of Policy Modelling, 28, pp. 235-246.

Granger, C.W.J. (1968). Investigating causal relations by econometric models and cross-spectra methods. Econometrica, 37(3), pp. 424-438.

Halit, $y$. (2002). Trade openness and economic growth: a cross-country empirical investigation. Journal of Development Economics 72(2003), pp. 57-89.

Hamilton, J.D. (1994). A new approach to the economic analysis of nonstationarity time series and the business cycle. Journal of Econometric Society 57(2), pp. 357-384.

Harris, R. (1996). Using cointegration analysis in econometric modelling. Journal of Applied Econometrics, 11(2), pp. 211-215.

Huang, B-N and Yung, C.W. (1996). Long-run purchasing power parity revisited: a Monte Carlo simulation. Applied Economics, 28(8), pp. 967-974.

Johansen, S. (1988). Statistical analysis of cointegration vectors. Journal of Economic Dynamics and Control, 12, pp. 231-254.

Katerina, L., Papanastasiou, J. and Vamvakidis, A. (2004). Foreign direct investment and economic growth in transition economies. South Eastern Europe Journal of Economics 1(2004), pp. 97-110.

Kohpaiboon, A. (2004). Foreign trade regime and FDI-growth nexus: a case study of Thailand. The Journal of Development Studies, 40(2), pp. 55-66.

Lipsey, R.E. (2000). Inward FDI and economic growth in developing countries. Transnational Corporations, 9(1), pp. 61-95.

Malefane, M.R. (2007). Determinants of foreign direct investment in Lesotho: evidence from cointegration and error correction modelling. Southern African Journal of Economic and Management Sciences, 10(1).

Mansouri, B. (2005). The interactive impact of FDI and trade openness on economic growth: evidence from Morocco. Proceedings of the $12^{\text {th }}$ Economic Research Forum Conference, December, Cairo.

Melnyk, L., Kubatko, O. and Pysarenko, S. (2014). The impact of FDI on economic growth: case of post communism transition economies. Problems and Perspectives in Management, 12(1), pp. 16-24.

Pahlavani, M., Wilson, $\varepsilon$., and Worthington, A.C. (2005). Trade-GDP nexus in Iran: an application of autoregressive distributed lag (ARDL) model. American Journal of Applied Sciences, 2(7), pp. 1158 1165.

Pesaran, M.H. and Pesaran, B. (2001). Working with microfit 4.0: interactive econometric analysis. Oxford University Press.

Phillips, P.C.B. and Perron, P. (1988). Testing for a unit root in time series regression. Biometrica 75(2), pp. 335-346. 
Prebisch, R. (1968). Development problems of the peripheral countries and the terms of trade. In J.D. Theberge (ed.) Economics of trade and development. New York: John Wiley and Sons Inc.

Ramirez, M.D. (2000). Foreign direct investment in Mexico: a cointegration analysis. Journal of Development Studies, 37(1), pp. 138-162.

Reimers, H.E. (2002). Comparison of tests for multivariate cointegration. Statistical Papers, 33(1), pp. 335-359.

Saltz, S. (1992). The negative correlation between foreign direct investment and economic growth in the third world: theory and evidence. Rivista Internazionale di Scienze Econometriche e Commerciali, 39, pp. 617-633.

Schoors, K. and Merlevede, B. (2004). "Gradualism versus Big Bang: Evidence from Transition Countries," Working Papers of Faculty of Economics and Business Administration, Ghent University, Belgium 04/243, Ghent University, Faculty of Economics and business administration

Seetanah, B. (2009). Is foreign direct investment growth conducive? New evidences from SubSaharan African countries, 1980 - 2005. Applied Econometrics and International Development, 9(2).

Singer, H.W. (1950). The distribution of gains between investing and borrowing countries. American Economic Review, 40(2), pp. 473-485.

Soliu, A. and Ibrahim, 0. (2014). Empirical analysis of trade openness, capital formation, FDI and economic growth: Nigeria experience. 1 (1), pp. 36-50.

Ullah, I., Shah, M. and Khan, F. (2014). Domestic investment, FDI and economic growth nexus: case of Pakistan. Economics Research International, 2014(2014).

United Nations Conference on Trade and Development (UNCTAD) (2003). Lesotho Investment Policy.

World Bank Economic Review (1993). Measuring the dynamic gains from trade. The World Bank Economic Review, 15(3), pp. 393-429.

Yaoxing, Y. (2010). The relationship between foreign direct investment, trade openness and growth in Cote d'Ivoire. International Journal of Business and Management, 5(7). 


\section{APPENDIX}

TABLE Al: Estimated Long-Run Coefficients using the ARDL Approach

Dependent variable is $y$

\begin{tabular}{cccc}
\hline Regressor & Coefficient & Std.Error & Prob \\
\hline FDI & -0.0172 & 0.0108 & 0.127 \\
K & 0.0690 & 0.0400 & 0.099 \\
L & 0.8819 & 0.1511 & 0.000 \\
T0 & -0.2752 & 0.0461 & 0.000 \\
D98 & 0.0405 & 0.0249 & 0.120 \\
LHDP & 0.0414 & 0.1211 & 0.003 \\
\hline
\end{tabular}

TABLE A2: Error Correction Representation for the Selected ARDL Model

Dependent variable is $y$

\begin{tabular}{|c|c|c|c|c|}
\hline Regressor & \multicolumn{2}{|c|}{ Coefficient } & $\begin{array}{l}\text { Standard } \\
\text { Error }\end{array}$ & Prob. \\
\hline $\mathrm{dFDI}$ & \multicolumn{2}{|c|}{-0.008040} & 0.004609 & 0.093 \\
\hline $\mathrm{dK}$ & \multicolumn{2}{|c|}{0.074607} & 0.022120 & 0.002 \\
\hline$d L$ & \multicolumn{2}{|c|}{0.340390} & 0.091000 & 0.001 \\
\hline dTO & \multicolumn{2}{|c|}{0.039400} & 0.029029 & 0.187 \\
\hline ecm $(-1)$ & \multicolumn{2}{|c|}{-0.271480} & 0.073987 & 0.001 \\
\hline \multicolumn{3}{|l|}{ R-Squared } & R-Bar-Squared & 0.638050 \\
\hline \multicolumn{2}{|c|}{ S.E. of Regression } & 0.009007 & F-Stat & 10.31420 \\
\hline \multicolumn{2}{|l|}{$\begin{array}{l}\text { Mean of } \\
\text { Variable }\end{array}$} & 0.008273 & S.D. Dependent Var & 0.014972 \\
\hline \multicolumn{2}{|c|}{ Residual Sum of Squares } & 0.001703 & Log-likelihood & 108.0508 \\
\hline \multicolumn{2}{|l|}{ AIC } & 98.05080 & SBC & 90.88080 \\
\hline \multicolumn{2}{|c|}{ DW-statistic } & 2.99170 & & \\
\hline
\end{tabular}

SBC denotes Schwarz Information Criterion 
TABLE A3: Descriptive statistics

\begin{tabular}{cccccc}
\hline & $\mathrm{Y}$ & $\mathrm{TO}$ & $\mathrm{L}$ & $\mathrm{K}$ & $\mathrm{FDI}$ \\
Mean & 3.523966 & -0.301161 & 5.873368 & 8.424982 & 7.415597 \\
Median & 3.519844 & -0.276602 & 5.885796 & 8.451608 & 7.461948 \\
Maximum & 3.693609 & 0.027920 & 5.969901 & 8.693968 & 8.458630 \\
Minimum & 3.398260 & -0.545795 & 5.745960 & 8.098806 & 6.314106 \\
Std. Dev. & 0.084785 & 0.148517 & 0.064790 & 0.157565 & 0.700230 \\
Skewness & 0.298423 & 0.078408 & -0.425926 & -0.108585 & -0.100575 \\
Kurtosis & 1.988070 & 2.529232 & 1.888966 & 1.977322 & 1.745155 \\
\hline
\end{tabular}

